\title{
Outcomes of Endovenous Cyanoacrylate Closure Using Venaseal System for Chronic Venous Insufficiency
}

\author{
Bahar Temur ${ }^{1}$ (D) , Selim Aydın ${ }^{1}$ (iD
}

${ }^{1}$ Acıbadem Mehmet Ali Aydınlar University, School of Medicine, Department of Cardiovascular Surgery, Istanbul, Turkey

\section{Bahar TEMUR}

Selim AYDIN

Correspondence: Bahar Temur Acıbadem Mehmet Ali Aydınlar University, School of Medicine, Department of Cardiovascular Surgery, Istanbul, Turkey Phone: +902124044177

E-mail: bahar.temur@acibadem.com

\begin{abstract}
Purpose: Endovenous cyanoacrylate closure of saphenous veins is a nonthermal, nonsclerosant ablation technique with satisfactory results. The objective of this study is to indicate the impact of Venaseal closure system in chronic venous insufficiency.

Methods: Between March 2014- March 2019, 27 patients underwent a total of 40 procedures with the VenaSeal closure system for symptomatic saphenous vein reflux in our hospital. Beside glue ablation procedures, 16 patients underwent concomitant mini phlebectomy, 3 patients underwent perforan vein ligation and 1 patient underwent anterior accessory saphenous vein ligation. The mean age of the patients were 44.4 \pm 13.8 (19-67). Doppler ultrasound of the target vein was performed one and 12 months after treatment. Tumescent anesthesia and compression stockings were not used.

Results: Mean follow up time was $34.3 \pm 17$ months. The anatomical success rate was $100 \%$ at 1 month and $100 \%$ at 1 year and there was no recanalization in treated vein segment. All procedures were well tolerated with a median visual analog scale (VAS) pain score of 3.0 (range: 2-5) on a 10-point scale. The mean pre-operative revised venous clinical severity score was $7.5 \pm 2.6$, which improved to $2.6 \pm 0.7, \mathrm{p}<0.001$ at one month follow-up. Deep vein thrombosis and pulmonary thromboembolism were not detected. Phlebitis was seen in $2(7,4 \%)$ patients and hypersensitivity reaction occured in one patient $(3,7 \%)$.
\end{abstract}

Conclusion: Endovenous cyanoacrylate closure of refluxing saphenous veins offers a safe and effective treatment with reduced side effects.

Keywords: Cyanoacrylate; saphenous vein; tumescent anesthesia; venous insufficiency

Kronik Venöz yetmezlikte Venaseal Sistemi kullanılarak yapılan endovenöz siyanoakrilat ile kapatma tedavisinin sonuçları

Öz

Amaç: Safen venlerin endovenöz siyanoakrilat ile kapatılması, termal ve sklerozan olmayan ve tatmin edici sonuçlara sahip bir ablasyon tekniğidir. Bu çalışmanın amacı, Venaseal kapatma sisteminin kronik venöz yetmezlikteki etkinliğini göstermektir.

Yöntem: Mart 2014 - Mart 2019 tarihleri arasında hastanemizde 27 hastaya semptomatik safen ven reflüsü için VenaSeal kapatma sistemi ile toplam 40 işlem uygulandı. Yapıştııı ı ablasyon işlemlerinin yanı sıra 16 hastaya eş zamanlı mini flebektomi, 3 hastaya perforan ven ligasyonu ve 1 hastaya ön aksesuar safen ven ligasyonu yapıldı. Hastaların yaş ortalaması 44,4 \pm 13,8 (19-67) idi. Tedaviden 1 ve 12 ay sonra hedef damara Doppler ultrasonografi yapıldı. Tümesan anestezi ve kompresyon çorapları kullanılmadı.

Bulgular: Ortalama takip süresi $34.3 \pm 17$ aydı. Anatomik başarı oranı 1 ayda $\% 100,1$ yılda $\% 100$ idi ve tedavi edilen ven segmentinde rekanalizasyon görülmedi. Tüm prosedürler, 10 puanlık bir ölçekte, medyan görsel analog skala (VAS) ağrı skoru 3.0 (aralık: 2-5) ile iyi tolere edildi. Ortalama preoperatif revize venöz klinik şiddet skoru (VCSS) $7.5 \pm 2.6$ idi ve bir aylık takipte $2.6 \pm 0.7^{\prime}$ ye düştü $(p<0.001$ ). Derin ven trombozu (DVT) ve pulmoner tromboembolizm (PTE) tespit edilmedi. Flebit $2(\% 7,4)$ hastada görüldü ve bir hastada $(\% 3,7)$ aşııı duyarlııı reaksiyonu meydana geldi.

Sonuç: Safen ven reflüsünde endovenöz siyanoakrilat kapatma, yan etkileri azaltılmış güvenli ve etkili bir tedavi sunmaktadır.

Keywords: Safen ven; siyanoakrilat; tümesan anestezi; venöz yetersizlik

$\begin{array}{ll}\text { Received } & : 15 \text { June } 2021 \\ \text { Accepted } & : \text { : } 20 \text { August } 2021\end{array}$


$\mathbf{T}$ he treatment of chronic venous insufficiency (CVI) has been changed recently with the discovery of endovenous thermal ablation (ETA) techniques to treat the refluxing superficial saphenous veins. These techniques became guidelined therapy for varicose veins after saphenous vein stripping and high ligation (1). They are very effective but also painful methods with a plenty number of side effects like irritation, ecchymosis, paresthesia (2). The VenaSeal ${ }^{\mathrm{TM}}$ closure system (Medtronic, Minnesota, USA) is a a non-thermal, non-tumescent endovenous ablation system which contains a medical tissue adhesive called $n$-butyl-2 cyanoacrylate and it is injected endovenously to treat superficial chronic venous incompetence. The cyanoacrylate tissue adhesive causes an inflammatory process and fibrosis when it meets with endothelium of the vein which results in closure of the treated vein segment (3). Side effects like pain and phlebitis are rare and patient satisfaction scores are high (4).

The objective of this paper is to report our experience with VenaSeal ${ }^{\mathrm{TM}}$ glue closure system to treat incompetent great saphenous vein (GSV) and small saphenous vein (SSV), its safety and short and mid-term efficacy (one year).

\section{Material and Methods}

Between March 2014- March 201970 patients underwent endovenous ablation for GSV and/or SSV in our hospital. Among them 27 patients underwent glue ablation with the VenaSeal ${ }^{\mathrm{Tm}}$ closure system (Medtronic, Minnesota, USA). This study was approved by the institutional ethics committee.

The mean age of the patients were $44.4 \pm 13.8$ (19-67). Baseline characteristics of the patients are listed in Table 1. Fifteen ( $55.6 \%$ ) of them were female and $12(44.4 \%)$ of them were male. A total of 40 endovenous cyanoacrylate closure (ECC) procedures with the VenaSeal ${ }^{\mathrm{TM}}$ system were performed in these patients. Procedures are listed in Table 2. Nine patients underwent bilateral ablation. Beside ECC procedures, 16 patients underwent concomitant mini phlebectomy, 3 patients underwent perforator vein ligation and 1 patients underwent anterior accessory saphenous vein ligation. Venous ulcer debridement was performed in one patient in the same session. All patients had symptomatic venous reflux of GSV and/or SSV and varicosities with clinical-etiology-anatomy-pathophysiology (CEAP) classifications of C2-C4. The maximum treated venous diameter was $1.2 \mathrm{~cm}$. The median diameter of GSV was 7,5 (5-12) $\mathrm{mm}$ and the median diameter of SSV was $6,5(5-8,4) \mathrm{mm}$.

\section{Table 1: Baseline characteristics of the patients}

\begin{tabular}{|l|l|}
\hline Characteristics & Cyanoacrylate closure (n:27) \\
\hline Age, mean \pm SD (range), years & $44.4 \pm 13.8(19-67)$ \\
\hline $\begin{array}{l}\text { GSV diameter; median (range), } \\
\text { mm }\end{array}$ & $7,5(5-12)$ \\
\hline $\begin{array}{l}\text { SSV diameter; median (range), } \\
\text { mm }\end{array}$ & $6,5(5-8,4)$ \\
\hline CEAP & C2-4 \\
\hline VCSS & $7.5 \pm 2.6$ improved to 2.6 \pm 0.7 \\
\hline VAS, (range) & $3.0(2-5)$ \\
\hline Follow up, mean $\pm S D$, months & $34.3 \pm 17$ \\
\hline $\begin{array}{l}\text { CEAP: clinical- etiology-anatomy-pathophysiology; GSV: Great saphenous } \\
\text { vein; SD:Standard derivation; SSV: Small saphenous vein; VAS: Visual analog } \\
\text { scale; VCSS:Venous clinical severity score }\end{array}$ \\
\hline
\end{tabular}

\begin{tabular}{|l|l|}
\hline Table 2: Procedures & $\mathrm{n}$ \\
\hline Procedure & 26 \\
\hline GSV ECC & 14 \\
\hline SSV ECC & 3 \\
\hline PERFORATOR VEIN LIGATION & 1 \\
\hline ACCESSORY VEIN LIGATION & 16 \\
\hline PHLEBECTOMY & 9 \\
\hline BILATERAL & ECC: Endovenous cyanoacrylate closure; GSV: Great saphenous vein; SSV: Small \\
\hline saphenous vein
\end{tabular}

In all patients, the procedure was performed in the operating room in a sterile fashion and with the technique that was previously published in VeClose study and the instruction manual of the manufacturer $(5,6)$. Venaseal ampule contains $5 \mathrm{~mL}$ of $\mathrm{n}$-butyl-2 cyanoacrylate. The saphenous vein was percutaneously cannulated beneath the knee with the help of Doppler ultrasound (DUS). The introducer sheath was entered into the saphenous vein and the catheter was moved forward $5 \mathrm{~cm}$ distal to the saphenofemoral junction (SFJ). N-butyl cyanoacrylate solution was put into the injection gun and the delivery catheter was inserted through the sheath. Compression was applied into the proximal segment to prevent glue from escaping into the deep venous system. The catheter was pulled back at $1 \mathrm{~cm}$ in the first shot, then $3 \mathrm{~cm}$ intervals. Compression was applied for 3 minutes at the end of the first $4 \mathrm{~cm}$, and then for 30 seconds in subsequent segments. The procedure was continued until all large saphenous vein parts were closed. Tumescent anesthesia (TA) was not required during the intervention and there was no need for compression stockings afterwards. All 
patients were discharged on the day of the procedure uneventfully.

\section{Statistical Analyses}

Data was analyzed with IBM SPSS for Windows version 20.0 (SPSS, Chicago, IL, USA). Kolmogorov-Smirnov test was used to test the normality of the data distribution. The continuous variables were stated as the mean \pm standard deviation and the median (25.percentiles-75.percentiles). The categorical variables were stated as counts (percentages). A P value $<0.05$ was taken as significant.

\section{Results}

VenaSeal $^{\mathrm{TM}}$ catheter was delivered to the planned position in all cases (100\% technical success). There wasn't any complication seen due to the device. Also there wasn't any need for a double puncture due to the tortuosity of the vein. All operations except two of them (one with multiple phlebectomies and one with venous ulcer debridment) were performed under local anesthesia. Patients were asked to return their normal activities as soon as possible. All of the patients had postprocedural DUS examination at the end of first month and all patients returned for ultrasound examination at the end of first year after the operation. Embolization through the whole treated vein segment with no parts of patency exceeding $5 \mathrm{~cm}$ in DUS examination was defined as closure. Recanalization was defined as opening along the treated vein segment exceeding $5 \mathrm{~cm}$ in length in DUS. Mean follow up time was $34.3 \pm 17$ months. The longest period of follow up was 60 months. The anatomical success rate was $100 \%$ at 1 month and $100 \%$ at 1 year and there was no recanalization in treated vein segment.

All procedures were well tolerated with a median visual analog scale (VAS) pain score of 3.0 (range: 2-5) on a 10-point scale, documented on the morning afterwards by calling all of the patients by phone. The mean preoperative revised venous clinical severity score (VCSS) was 7.5 \pm 2.6 , which improved to $2.6 \pm 0.7, p<0.001$ at one month follow-up.

We found no significant side effects and complications during follow-up. Major complications such as deep vein thrombosis (DVT) and pulmonary thromboembolism (PTE) were not detected. None of the patients had postablation thrombus extension through SFJ. Phlebitis was seen in $2(7,4 \%)$ patients and was treated with short time medical therapy with nonsteroidal anti-inflammatory medication (NSAIDS). Sensitivity reaction with erythema and aching occured in one patient $(3,7 \%)$ who was totally recovered with NSAIDS.

\section{Discussion}

The treatment of varicose veins vary from stripping and high ligation of safenous veins to endovascular ablation procedures. Many recent studies proved that endothermal ablation techniques are highly effective in venous insufficiency (7-9). Rasmussen et al. (8) reported 12-month closure rates of $94.2 \%$ for radiofrequency ablation (RF) , 95.2\% for laser ablation, 95.2\% for stripping, and $83.7 \%$ for sclerotherapy. Cyanoacrylate is an adhesive which has already been used for the embolization of arteriovenous malformations and management of esophageal varices $(10,11)$. It provides quick polymerization upon contact with blood, obliterates the vein by creating fibrosis and this prevents embolization of the glue to the deep venous system with a proper distance. In our report none of the patients had postablation thrombus extension through SFJ. Almeida et al. (12) documented the first use of cyanoacrylate in refluxing GSV in 2013 and two-year results were published later (13). 38 patients with a GSV mean diameter of $6.7 \mathrm{~mm}$ were included in the study and the mean operation time was 21 minutes. The closure rate of 24-month was $92.2 \%$.

In VenaSeal Sapheon Closure System Pivotal Study (VeClose) that compares RF ablation and cyanoacrylate closure, treatment with the cyanoacrylate was found to be safe and effective in the management of great saphenous vein insufficiency with freedom from recanalization of $91,4 \%$ and with low additional procedure rates in both groups in five year follow-up (14). Also in our cohort, the closure rate was $100 \%$ at 1 month and $100 \%$ at 1 year and there was no recanalization in treated vein segment. The maximum venous diameter in our report was $1.2 \mathrm{~cm}$ but veins with larger diameters can be treated with $\operatorname{ECC}(4,15)$.

In Waves study (4) which shows outcomes of Venaseal ${ }^{\mathrm{TM}}$ procedure, high occlusion rates were obtained without using compression stockings. Improvements in quality of life and venous severity scores were significant and back to normal activities time was short. In our study, the mean pre-operative VCSS was $7.5 \pm 2.6$ improved to $2.6 \pm 0.7, \mathrm{p}<$ 0.001 at one month follow-up. 
A European prospective multicenter study showed results of VenaSeal ${ }^{\mathrm{TM}}$ treatment in 70 patients with a $92.9 \%$ closure rate at 12-months (5). In this study, compression socks and TA were not used. Mild phlebitis was seen in $11.4 \%$ of the patients. Thromboembolic incidents were not noticed. We also didn't use compression stockings after the operations which increased patient comfort. We advice our patients to get back to normal daily activities as soon as possible. Major complications such as deep vein thrombosis (DVT) and pulmonary thromboembolism (PTE) were not detected.

Thermal ablation has side effects like skin pigmentation, paresthesia and prolonged deafness feeling due to nerve irritations especiallly in SSV interventions and these techniques require the use of TA (2). This prolongs the duration of the procedure and tumescent injections may cause ecchymosis, pain, and hematoma $(16,17)$. Patient comfort may be another reason for glue ablation of the veins to be a recommendation. In our report all procedures were well tolerated with a median VAS pain score of 3.0 (range: $2-5$ ) on a 10-point scale, We consider concomitant phlebectomies can make the pain scores worse. Park et al. (18) mentioned 271 procedures in 160 patients with Venasea ${ }^{\mathrm{TM}} \mathrm{Clo}^{-}$ sure and $69(25,4 \%)$ of these treated veins experienced a phlebitis like skin condition with erythema, itching, swelling, pain and tenderness that develops suddenly after several days of cyanoacrylate closure.They used steroids and antihistamines for treatment. According to some of the studies this phlebitis-like situation is an allergic or a foreign body reaction to cyanoacrylate with a histotoxic background $(4,19)$. Gibson et al. $(20)$ demonstrated that hypersensitivity reactions happened in $6.0 \%$ of 286 patients treated with glue ablation and most of them were mild. Lew et al. (21) reported a patient who developed multiple pustules with surrounding erythema along the treated veins 2 weeks after enovenous glue ablation. This allergic reactions was managed by immediate removal of the adhesive. In our report 2 (7,4\%) patients had phlebitis and were treated with NSAIDs. Sensitivity reaction with erythema and aching occured in one patient $(3,7 \%)$ who was totally recovered again with NSAIDS. Side effects such as skin pigmentation or paresthesia were not seen in our patients.

There was no device-related complication and no serious adverse event was registered at a mean $34.3 \pm 17$ months' follow-up so our findings suggest that the VenaSeal ${ }^{\mathrm{TM}}$ procedure is safe and practicable with satisfactory results.

\section{Study Limitations}

Our study has some notable limitations. Principally, it is a retrospective study of one single centre with a small group of patients. Multicenter analyses may help to identify the outcomes of ECC.

\section{Conclusion}

Considering the advantages of glue ablation like avoidance of TA, reduced side effects and low pain score, ability of the patients to return to normal activities in general without the need for compression stockings, it can be the primary treatment of chronic venous insufficiency.

\section{Declarations}

Funding: The authors declared that this study received no financial support.

Conflicts of interest/Competing interests: No conflict of interest was declared by the authors.

Ethics approval: This study was conducted in accordance with the Declaration of Helsinki and approved by the institution's Ethics Committee (decision number: 202110/16 decision date: 09.06.2021).

Availability of data and material: The authors confirm that the data supporting the findings of this study are available within the article [and/or] its supplementary materials.

\section{References}

1. Tang TY, Rathnaweera HP, Kam JW, et al. Endovenous cyanoacrylate glue to treat varicose veins and chronic venous insufficiency Experience gained from our first 100. truncal venous ablations in a multi-ethnic Asian population using the Medtronic VenaSealTM Closure System. Phlebology. 2019;0(0):1-9.

2. Gibson K, Morrison N, Kolluri R, et al. Twenty-four month results from a randomized trial of cyanoacrylate closure versus radiofrequency ablation for the treatment of incompetent great saphenous veins. J Vasc Surg Venous Lymphat Disord. 2018;6:606-13.

3. Bademci MS, Kocaaslan C, Aldag M, et al. Single-center retrospective review of early outcomes of radiofrequency ablation versus cyanoacrylate ablation of isolated great saphenous vein insufficiency. J Vasc Surg Venous Lymphat Disord. 2019;7(4):480-485.

4. Gibson K, Ferris B. Cyanoacrylate closure of incompetent great, small and accessory saphenous veins without the use of post-procedure compression: Initial outcomes of a post-market evaluation of the VenaSeal System (the WAVES Study). Vascular. 2017; 25:149-156.

5. Proebstle TM, Alm J, Dimitri S, et al. The European multicenter cohort study on cyanoacrylate embolization of refluxing great saphenous veins. J Vasc Surg Venous Lymphat Disord. 2015;3:2-7.

6. Venaseal instructions for use, Medtronic Corporation, Dublin, Ireland, http://www.accessdata.fda.gov/ cdrh_docs/pdf14/P140018c.pdf (2015, accessed 16 May 2016).

7. De Maeseneer $\mathrm{M}$. The endovenous revolution. $\mathrm{Br} J$ Surg. 2011;98(8):1037-8. 
8. Rasmussen LH, Lawaetz M, Bjoern L, et al. Randomized clinical trial comparing endovenous laser ablation, radiofrequency ablation, foam sclerotherapy and surgical stripping for great saphenous varicose veins. Br J Surg. 2011; 98:1079-1087.

9. Morrison N, Gibson K, McEnroe S, et al. Randomized trial comparing cyanoacrylate embolization and radiofrequency ablation for incompetent great saphenous veins (VeClose). J Vasc Surg. 2015;61:985-994.

10. Ogilvy CS, Stieg PE, Awad I, et al. AHA Scientific Statement: Recommendations for the management of intracranial arteriovenous malformations: a statement for healthcare professionals from a special writing group of the Stroke Council, American Stroke Association. Stroke. 2001;32:1458-71.

11. Rosen RJ, Contractor S. The use of cyanoacrylate adhesives in the management of congenital vascular malformations. Semin Intervent Radiol. 2004;21:59-66.

12. Almeida JI, Javier JJ, Mackay E, et al. First human use of cyanoacrylate adhesive for treatment of saphenous vein incompetence. J Vasc Surg Venous Lymphat Disord. 2013;1:174-80.

13. Almeida Jl, Javier JJ, Mackay EG, et al. Two-year follow-up of first human use of cyanoacrylate adhesive for treatment of saphenous vein incompetence. Phlebology. 2015;30:397-404.

14. Morrison N, Gibson K, Vasquez M, et al. Five-year extension study of patients from a randomized clinical trial (VeClose) comparing cyanoacrylate closure versus radiofrequency ablation for the treatment of incompetent great saphenous veins. J Vasc Surg Venous Lymphat Disord. 2020;8:978-989.

15. Park I. Successful use of VenaSeal system for the treatment of large great saphenous vein of $2.84-\mathrm{cm}$ diameter. Ann Surg Treat Res. 2018;94(4):219-221.

16. Anwar MA, LaneTR, Davies AH, et al. Complications of radiofrequency ablation of varicose veins. Phlebology. 2012;27(Suppl):34-9.

17. Dexter $D$, Kabnick $L$, Berland $T$, et al. Complications of endovenous lasers. Phlebology. 2012;27(Suppl):40-5.

18. Park I, Jeong $\mathrm{MH}$, Park $\mathrm{CJ}$, et al. Clinical features and management of 'Phlebitis-like abnormal reaction' after cyanoacrylate closure for the treatment of incompetent saphenous veins. Ann Vasc Surg. 2019;55:239-45.

19. Park I. Initial outcomes of cyanoacrylate closure, Venaseal system, for the treatment of the incompetent great and small saphenous veins. Vasc Endovascular Surg. 2017;51:545-9.

20. Gibson K, Minjarez R, Rinehardt E, et al. Frequency and severity of hypersensitivity reactions in patients after Venaseal ${ }^{\mathrm{TM}}$ cyanoacrylate treatment of superficial venous insufficiency. Phlebology. 2019;35(5):337-344.

21. Lew PS, Tan YK, Chong TT, et al. VenasealTM Cyanoacrylate Glue Rejection Following Endovenous Ablation -Another New Complication. Biomed J Sci \& Tech Res. 2019;17(4):12993-12994. 